\title{
Foie gras and liver regeneration: a fat dilemma
}

\author{
Maria Agnese Della Fazia ${ }^{1, *}$ and Giuseppe Servillo ${ }^{1, *}$ \\ ${ }^{1}$ Department of Experimental Medicine, University of Perugia, Perugia, Italy. \\ * Corresponding Authors: \\ M.A. Della Fazia, Department of Experimental Medicine, University of Perugia, piazza Severi 1, 06132 Perugia, Italy. Tel: 075585 \\ 8111; E-mail: mariaagnese.dellafazia@unipg.it; \\ G. Servillo, Department of Experimental Medicine, University of Perugia, piazza Severi 1, 06132 Perugia, Italy. Tel: 0755858110 ; \\ E-mail: giuseppe.servillo@unipg.it
}

ABSTRACT The liver has a unique ability of regenerating after injuries or partial loss of its mass. The mechanisms responsible for liver regeneration mostly occurring when the hepatic tissue is damaged or functionally compromised by metabolic stress - have been studied in considerable detail over the last few decades, because this phenomenon has both basic-biology and clinical relevance. More specifically, recent interest has been focusing on the widespread occurrence of abnormal nutritional habits in the Western world that result in an increased prevalence of non-alcoholic fatty liver disease (NAFLD). NAFLD is closely associated with insulin resistance and dyslipidemia, and it represents a major clinical challenge. The disease may progress to steatohepatitis with persistent inflammation and progressive liver damage, both of which will compromise regeneration under conditions of partial hepatectomy in surgical oncology or in liver transplantation procedures. Here, we analyze the impact of ER stress and SIRT1 in lipid metabolism and in fatty liver pathology, and their consequences on liver regeneration. Moreover, we discuss the fine interplay between ER stress and SIRT1 functioning when contextualized to liver regeneration. An improved understanding of the cellular and molecular intricacies contributing to liver regeneration could be of great clinical relevance in areas as diverse as obesity, metabolic syndrome and type 2 diabetes, as well as oncology and transplantation. doi: $10.15698 /$ cst2018.07.144

Received originally: 21.11 .2017

in revised form: 18.05.2018,

Accepted 22.05.2018,

Published 14.06.2018.

Keywords: liver regeneration, Fatty Liver, ER-stress, NAFLD, SIRT1, Lipid metabolism, steatosis.

\section{Abbreviations:}

ER - Endoplasmic Reticulum, ERAD - ERassociated degradation,

NAFLD - non-alcoholic fatty liver disease,

NASH - non-alcoholic steatohepatitis, $\mathrm{PH}$ - partial hepatectomy,

$U P R$ - unfolded protein response.

\section{INTRODUCTION}

The liver has a unique ability to recover its mass after parenchymal tissue loss, a phenomenon known as liver regeneration [1-3]. Traditionally, not only does liver regeneration represent an experimental means of elucidating the basic biology of hepatocyte proliferation, but it is also important from a clinical perspective, in that the liver can be injured by a variety of different noxae, including metabolic diseases, infections, toxin-related pathologies, and autoimmunity [4-6]. Liver regeneration is likewise important in surgery, as partial hepatectomy $(\mathrm{PH})$ can be performed as a means of treating hepatocellular carcinoma, and it is used in liver transplantation from live donors as well [7-9].

A dramatic increase in hepatic steatosis is being observed over the past few years. Non-alcoholic fatty liver disease (NAFLD) - a liver pathology closely associated with insulin resistance and the dyslipidemia-metabolic syndrome [10-12] - is present in a percentage as high as approximately $20-30 \%$ of any apparently healthy western populations, thus representing a clinical challenge worldwide [13]. Moreover, a significant percentage of individuals with NAFLD will progress to non-alcoholic steatohepatitis (NASH) [14-16]. Considering that as many as $25 \%$ patients with NASH will develop cirrhosis, it can be assumed that about $2 \%$ of people currently with NAFLD are expected to progress to cirrhosis [12, 17]. Moreover, patients with NAFLD have an increased risk of developing hepatocellular carcinoma (HCC) [18]. Of note, in liver transplantation, macroscopic steatosis is associated with a higher risk of graft malfunctioning in the recipient. Because of so high a 
percentage of people with NAFLD, many potential donors are not eligible for donation [9].

Studies in rodents and humans have demonstrated an altered liver-regeneration pattern associated with fatty liver diseases [19-22]. In all of those pathological conditions, an improved understanding of the molecular mechanisms underlying liver regeneration would be of great value from both a basic biology and clinical points of view. In this review, we will focus on the pathophysiology of fat accumulation in the liver and its consequences on liver regeneration as well as liver diseases of major relevance.

\section{LIVER REGENERATION IN EXPERIMENTAL MODELS}

The liver presents two specific peculiarities in that it (a) maintains the homeostasis of all of the most important metabolic pathways (as regards lipids, carbohydrates and proteins) in the body [23-26] and (b) will reconstitute the original hepatic mass after injuries or partial removal of its parenchymal tissue. The two properties are interrelated, and any anomalies in metabolic homeostasis are reflected in altered liver-regeneration patterns. The capacity of the residual hepatocytes to proliferate after $\mathrm{PH}$ has been widely used as an experimental model of hepatocyte proliferation in vivo $[1-3,27]$. Two important aspects of liver regeneration have been considered in detail, namely, (a) the proliferative wave whereby stable cells begin to replicate in a synchronous way, and (b) the proliferative arrest occurring when replicating cells have reconstituted the original mass.

Since the first scientific report on liver regeneration one hundred years ago [28], many efforts have been made to clarify the underlying signals and mechanisms, both cellular and molecular in nature. Over the years, many molecules have been credited with an important role in liver regeneration, but none of them have been proven to represent, singly, the pivotal factor in liver mass reconstitution [29-32]. With the advent of genetically deficient knockout (KO) mice, several molecular pathways associated with those molecules have been identified as critically intercrossing at the interface of the proliferative wave and the subsequent proliferative arrest during regeneration. More often than not, the lack of a single - albeit relevant - gene in KO mice was only found to delay the process of liver regeneration, pointing to the mechanistic intricacies, and perhaps the redundancy thereof, whereby many molecules and pathways contribute to liver reconstitution [33-35].

Nelson Fausto proposed to assign molecules and mechanisms involved in liver regeneration to three major categories, namely, cytokines, growth factors and metabolic networks. In the process of liver regeneration, a variety of genes need to modify their expressions. An early set of genes is required to initiate proliferation in otherwise stable cells, which are thus forced to duplicate [36]. An initial "priming phase" is, in fact, driven primarily by cytokines, such as IL-6 and TNF $\alpha$ [37], and cAMP [32]. By recruiting NF-KB, STAT3 and PKA, a wide number of genes become transcriptionally activated and coordinately act on residual hepatocytes [36], so to result - in turn - in transcriptional activation of the so-called early genes (such as c-fos, c-myc, and $c$-jun), which initiate the actual process of liver regeneration [38, 39]. Although those factors and factorencoding genes involved in priming were previously thought as being essential to the regeneration process, studies in $\mathrm{KO}$ mice with $\mathrm{PH}$ have later shown that their respective genetic deficiencies cause only a delay in growth kinetic patterns, rather than a block in cell proliferation or an increased mortality. Therefore, the many factors associated with the priming phase do contribute to regeneration but are dispensable for overall successful completion of the process over the longer term.

The priming phase that primes residual hepatocytes for subsequent proliferation requires that growth factors trigger the transition from the $G 1$ to the $S$ phase in hepatocytes. Increased levels of hepatocyte growth factor (HGF) and epidermal growth factor (EGF) - together with the activation of the respective receptors - have long been known to be a prerequisite for proliferation [40-43]. However, a variety of additional growth factors are now known to be crucially involved in this initial process [44]. Remarkably, despite these changes in transcriptional programs, residual hepatocytes maintain an ability to meet the basic metabolic requirements of the whole body (in terms of glucose, amino-acid, and lipid metabolism). Even when as little as $30 \%$ (or even less) of the initial mass remains functional, metabolic homeostasis is not compromised to the benefit of the newly started proliferative process.

Notably, the many studies on liver regeneration are not to be taken as a merely mechanistic analysis of how stable cells are forced to expand; rather, they represent an extremely useful model to gain insight into basic biology issues [45-49] as well into the pathophysiology of liver functioning, with general regard to hepatology, transplantation, and hepatocellular carcinoma treatment [9]. Many of those studies on liver regeneration have been making use of genetically deficient $\mathrm{KO}$ mice, with the aim of dissecting the contributions of individual genes to the regeneration process. It was only recently that one - perhaps, more clinically relevant - approach has come of age as a way to expand upon the previous information, namely, the analysis of the different patterns of liver regenerations in mice with specific dietary restrictions, such as low- or high-fat diets, lowor high-carbohydrate diets, and diets with low or high protein content $[50,51]$.

Many questions still remain unanswered, mainly as to the dynamics of liver regeneration [21, 52]. Among those, one of the most crucial is the functional significance of the transient steatosis observed in residual hepatocytes after $\mathrm{PH}$ [53-56]. The issue has been widely investigated in a variety of experimental models. Over the first few hours of $\mathrm{PH}$, the liver accumulates lipids, an event that is indispensable to successful liver regeneration $[19,57]$. The major lipids being stored are free fatty acids, which are mostly mobilized from adipose tissue, with only a minority of them being derived from hepatic synthesis [58-60]. In most studies, those lipids have been identified as being the "fuel" necessary to ignite liver regeneration [61-63]. Additional studies - using blockade of fat accumulation either by 
drugs or in specific KO mice - have indicated that not only does the transient steatosis fuel the process, but it also drives the correct modality of regeneration [22]. Yet, the precise mechanisms governing such a complex phenomenon have been unclear. Perhaps one consideration holds true: after $\mathrm{PH}$, reconstitution of the liver mass has a priority, and the accumulated lipids need to be utilized as a source of energy to guarantee proper regeneration [64] (Fig.1).

\section{LIPID METABOLISM IN LIVER AND ER STRESS}

The liver has an essential role in controlling lipid metabolism in the whole body. Cholesterol and fatty acids can be also synthesized and regulated in the liver, which coordinates the assembly of lipoproteins, mainly LDL (low density lipoprotein) and VLDL (very low density lipoprotein) [23, 24 65]. Under normal conditions, an overall balance between input and output of lipids in liver is maintained. Changes in this balance predispose to specific diseases such as fatty liver disease.

An important role in lipid metabolism is played by the Endoplasmic Reticulum (ER) $[66,67]$. Several enzymes and proteins involved in lipid metabolism are present in the ER [68-70]. Many physio-pathologic conditions will alter ER homeostasis and induce ER stress [71-73]. A rapid request for secretory or membrane protein synthesis, as it occurs in liver regeneration, or alterations in redox or $\mathrm{Ca}^{2+}$ homeostasis, are conditions whereby the ER is subjected to high levels of stress [74, 75]. In response to many stressors, the ER triggers a well-defined process that causes the cell either to restore normal functioning or to undergo apoptosis. To accomplish the former outcome - and circumvent any potentially dangerous effects of unfolded or misfolded proteins - the ER resorts to a system of protein-quality control referred to as ER-associated degradation or ERAD [76-78]. If ERAD, however, fails to restore protein homeostasis, the ER activates a more complex system, namely, the unfolded protein response (UPR) [79-81]. The UPR system comprises three pathways involving transcriptional or translational regulators aimed at normalizing ER function. UPR represents a major stress pathway controlled by the chaperone 78-kDa glucose-regulated protein (GRP78) to mediate IRE1, PERK, and ATF6 signaling [82-85]. Those three proteins - namely, PKR-like ER kinase (PERK), inositol-requiring enzyme-1 (IRE1), and cyclic-AMP-dependent transcription factor ATF-6 $\alpha$ (ATF6) - are, under normal conditions, linked to the ER-chaperone GRP78. Upon ERstress induction, GRP78 binds the unfolded or misfolded proteins as they are released in the ER lumen, thus enabling activation of the three transmembrane proteins involved in UPR. When activated, PERK homodimerizes and, in turn, phosphorylates the eukaryotic initiation factor $2 \alpha$ (elF $2 \alpha$ ), which prevents the 80 S ribosome assembly, leading to the arrest of protein synthesis $[82,86]$.

Even though phosphorylation of elF $2 \alpha$ arrests protein synthesis it allows the translation of selected protein in-

\section{Partial Hepatectomy}

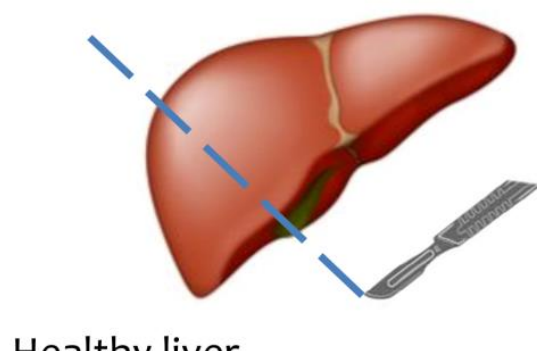

Healthy liver
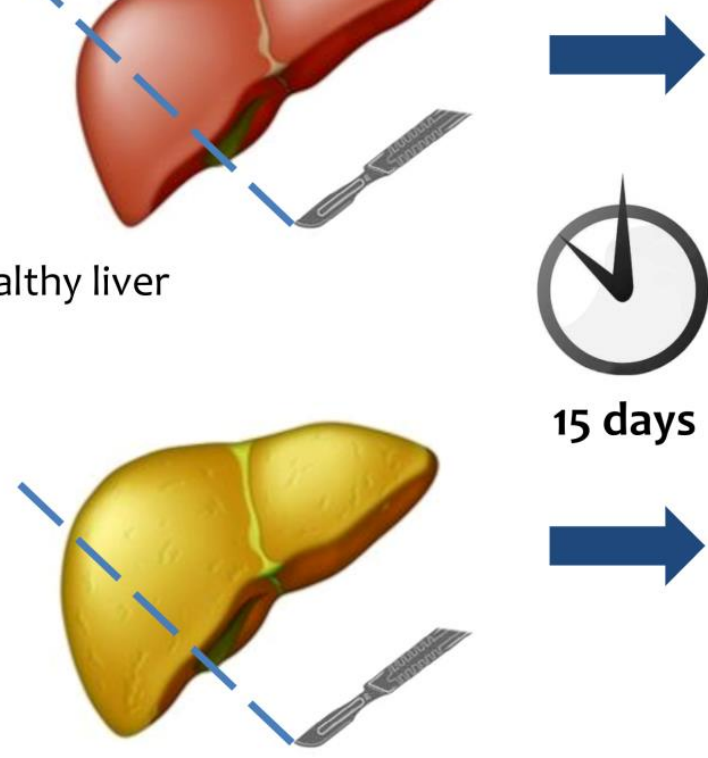

15 days

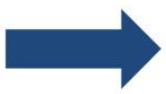

\section{Regenerating liver}
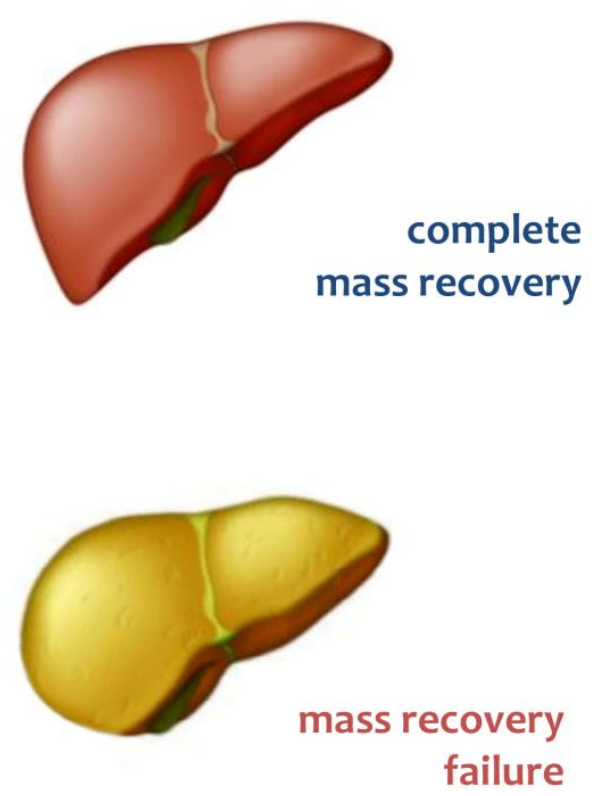

Fatty liver

FIGURE 1: Liver regeneration failure in fatty liver. After $\mathrm{PH}$, healthy liver can completely restore its mass and functional activity within 15 days. In fatty liver mass and functional recovery is compromised. 
cluding the transcription factor ATF4, which is overexpressed during ER stress and regulates expression of a number of genes responsible for amino-acid metabolism and apoptosis, including C/EBP homologous protein (CHOP) [87]. Notably, ATF4 controls the expression of GADD34, which in turn plays an important role in dephosphorylating elF $2 \alpha$, thus activating a key feedback mechanism to restore protein synthesis [88]. Of note, elF2a can be phosphorylated not only via activation of the UPR system, but also by other kinases involved in the stress response [89].

The ER stress-driven UPR system makes use of another transmembrane protein, IRE1. IRE1 is a multifunctional protein, capable of kinase and ribonuclease activities [90]. The RNAse activity allows the generation of a splicing form of the X-box-binding protein 1 (XBP1), which acquires an ability to transcribe ER-chaperons, proteins of the ERAD system, and proteins involved in fatty-acid metabolism [9193].

ATF6 is a further UPR-pathway protein activated by ER stress. ATF6 binds GRP78 in the ER, yet in response to stressors, it is released from GRP78 and migrates to the Golgi, where it is cleaved and moves to the nucleus. ATF6 works as a transcription factor coordinating the expression of different components of the UPR system (i.e., GRP78), ER-chaperones, XBP1, the pro-apoptotic factor $\mathrm{CHOP}$, as well as other components of ER-stress response [94, 95].

Finally, the cell to tackle against stressors has developed, ERAD, UPR, or autophagy, but in the case of failure in adaptive response the UPR sensors addressed the cell towards apoptosis [96] (Fig. 2).

\section{ER STRESS AND LIVER REGENERATION}

Because of the role of liver in controlling lipid homeostasis, it is clear that the UPR system is considered to be pivotal in the response to a number of stressors acting on hepatocytes. Chemical or naturally occurring toxicants act on hepatocytes and changes in cellular status - such as nutritional and proliferative changes or rapid functional requests - are accomplished via transient ER stress and UPR activation [97-100]. Indeed, proliferation of residual hepatocytes in the onset of liver regeneration needs abundant protein synthesis, which increases protein folding demand within the ER. At present, UPR function is considered a major component of liver regeneration. The analysis of pivotal players in UPR shows a triggering event during liver regeneration. Physiological response involves a rapid increase and activation of ER-stress genes after PH. IRE1a pathway, PERK, pIF2a and CHOP increase their expression in the first hours after partial hepatectomy [101-103].In particular, after a $70 \% \mathrm{PH}$, residual hepatocytes undergo changes that drive ER stress $[20,104]$. As a matter of fact, the residual tissue (30\%) needs to preserve the overall homeostasis in the body while engaged in reconstituting liver mass. The latter event requires that residual hepatocytes are able to synthesize and assemble all the cellular components needed for regeneration, which calls for the onset of a transient ER-stress status, the hallmark of which is temporary steatosis, reversed only by the time of regeneration completion $[20,53,64]$.

Such a bidirectional relationship would imply that an excess of dietary lipid intake resulting in steatosis might determine a status of chronic activation of the ER-stress response. Experiments in obese rodents have indeed provided evidence for the persistent activation of the UPR system, a condition shared clinically by patients with severe steatosis, NAFLD, or NASH [105-107]. The major mechanism responsible for the association between steatosis and activation of the UPR system seems to be related to changes in membrane fluidity and consequent loss of $\mathrm{Ca}^{2+}$ homeostasis. Changes in membrane composition and fluidity have been described in obese mice that display an altered ratio between the two main membrane phospholipids, phosphatidylcholine and phosphatidylethanolamine [108]. An altered ratio between the two phospholipids leads to ER membrane modification, which, in turn, affects $\mathrm{Ca}^{2+}$ homeostasis. As demonstrated by a series of elegant experiments, a decrease in $\mathrm{Ca}^{2+}$ causes remarkable stress in the ER via reduction in the $\mathrm{Ca}^{2+}$-dependent chaperone component. Overall, these data substantiate the role of lipids as one of the most important ER stressor [109, 110].

Many authors have identified ER stress as being, itself, the primary cause of the de novo synthesis of lipids either under conditions of steatosis-associated insulin resistance or of chronic ER stress-induced proteolytic cleavage of SREBP-1c, which translocates to the nucleus and activates a cohort of genes involved in lipogenesis [111]. Therefore, the outcome of chronic activation of ER stress by lipids is steatosis and subsequent onset of NAFLD. This is determined by lipid accumulation in the liver and ER-stress activation, which plays an important role per se in the pathogenesis of NAFLD, mainly by direct control of de novo lipogenesis and by mitochondria modifications [112, 113]. On the long term, chronic ER stress recruits additional mechanisms in the liver, including a reduction in VLDL secretion or a change in the insulin response, which exacerbates the condition [114]. Such a prolonged condition of the liver causes increased oxidative stress accompanied by inflammation and apoptosis, eventually resulting in the onset of NASH. Overall, chronic activation of ER stress is a pathological condition that determines a severe impairment in liver functioning [104, 115].

The regenerative ability of the liver under ER stress is altered and even in absence of severe steatosis or NAFLD, the residual hepatocytes have a delay in their ability to proliferate properly [116-118]. Recent studies in mice fed a high-fat diet for 10 weeks to induce steatosis showed that the classical genes involved in ER stress - with the exclusion of SXBP-1 - were not overexpressed. After PH, a delay in the proliferation of residual hepatocytes was observed in mice fed the high-fat diet; higher a ctivation of ER-stress genes, such as GRP78, IRE1a, ATF6, PERK, sXBP-1 and CHOP, was detected [20]. Moreover, persistent fat accumulation was present in mice fed the diet. Mice genetically deficient for the $3 \beta$-hydroxysterol $\Delta 14$-reductase (TM7SF2)encoding gene (TM7SF2 KO mice, which lack the ER enzyme involved in cholesterol synthesis) showed abnormal 


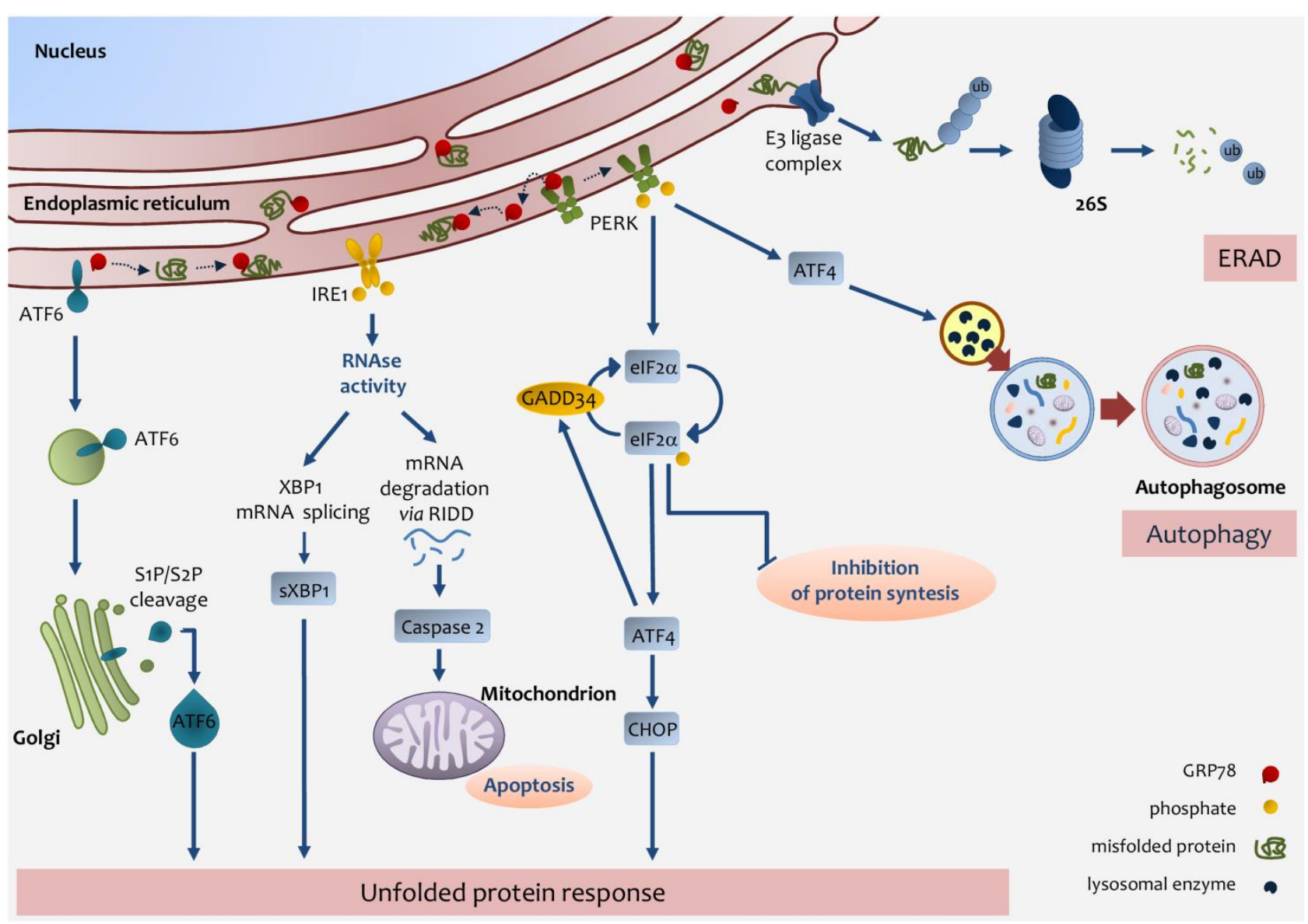

FIGURE 2: Endoplasmic reticulum (ER) stress pathways. ER stress occurs through the accumulation of misfolded proteins in the ER lumen. The role of the UPR is to re-establish ER homeostasis by reducing de novo protein synthesis and improving the folding and clearance capacity of the ER. The first mechanism against ER stress is ERAD, by which misfolded proteins are translocated back to the cytosol, ubiquitylated and degraded by the proteasome. When the level of misfolded proteins is too high, the cell activates UPR consisting in the activation of three transmembrane pathways. The main effectors are PERK, IRE1 and ATF6. Effectors activation is initiated by the removal of GRP78 allowing the translocation of the latter from the ER membrane to the ER lumen where it associates with unfolded proteins. elF $2 \alpha$ phosphorylation inhibits protein translation except for ATF4 which induces the expression of factors involved in antioxidant defence, amino acid metabolism, autophagy and apoptosis, such as CHOP. ATF4 also induces the expression of GADD34, which expression enables the dephosphorylation of elF2 $\alpha$ and the re-initiation of translation. PERK-mediated induction of ATF4, can also promote the expression of key autophagy-related proteins, which are needed for autophagosome formation. Once activated, IRE1 promotes the splicing of XBP1 mRNA, which is then translated into the active SXBP1, which transactivates the expression of components related to protein folding, ERAD and protein quality control. IRE1 also promotes the degradation of RNAs localized in the ER vicinity by regulated IRE1-dependent decay (RIDD), which induces caspase-2 and mitochondrial apoptosis. Upon GRP78 release, ATF6 is transferred to the Golgi apparatus as inactive precursors and cleaved by membrane-bound site-1 (S1P) and site-2 (S2P) proteases into an active form, which induces the expression of chaperones and UPR components. IRE1-mediated activation of XBP1 as well as ATF6 activation induces the expression of chaperones and UPR components.

activation of the ER-stress response. $\mathrm{PH}$ in TM7SF2 KO mice resulted in an impaired proliferation relative to wildtype counterparts, with a delay in the cell-cycle G1/S transition and early activation of GRP78. Furthermore, the KO mice accumulated an anomalous amount of hepatic triglycerides until 60 hours of PH. Unusual activation of p53 and persistently elevated levels of p21 were observed in the KO mice during liver regeneration. Because of the control of p21 on CHOP, it is conceivable that elevated level of p21 in those mice is related to the activation of the ERstress response by CHOP [104]. The analysis of liver regeneration after $\mathrm{PH}$ in different $\mathrm{KO}$ mice, in which any genes involved in ER-stress are deleted, shows regeneration ab- normalities with altered proliferation of the residual hepatocytes. Impairment in regenerative process has been detected in mice with IRE1a hepatocyte-specific deletion [101]. Moreover, the ER stress has been defined as an important cellular process in liver regeneration under Ischemia/Reperfusion Injury [119] as demonstrated in CHOP KO mice [120].

Whether a perturbation in the ER-stress response is directly responsible for the delay in liver regeneration, or an altered ER-stress response sustains fat accumulation responsible for the impaired liver regeneration, is still to be defined. 


\section{SIRTUINS AND LIPID METABOLISM}

Many studies have been describing an important role for sirtuins in the metabolism of liver lipids. Sirtuins are a family of proteins that share a number of functions and which conserve $\mathrm{NAD}^{+}$-dependent histone and protein deacetylase functions. In mammals there are seven sirtuins with different cellular functions ranging from energy metabolism, cellular stress resistance, genomic stability to aging and tumorigenesis [121, 122]. Each Sirtuin has distinct functions and subcellular localizations. SIRT1 and SIRT2 are in both the nucleus and the cytosol, SIRT3, SIRT4, and SIRT5 are in the mitochondria and SIRT6 and SIRT7 are localized in the nucleus [123]. Among them, SIRT1, SIRT3, SIRT6 and SIRT7 have been discovered as involved in fat liver metabolism [124-128].

The silent information regulator 1 (SIRT1) represents one of the best-characterized members of the mammalian sirtuin family of NAD-dependent histone deacetylases. SIRT1 is a nutrient sensor and has a crucial role in the control of ageing in different organisms [129]. Moreover, SIRT1 has a pivotal role in the control of normal liver function in mammals, participating in the regulation of metabolic processes such as gluconeogenesis, fatty acid $\beta$ oxidation and cholesterol flux [122].

Of particular interest, SIRT1 has been known as an important regulator of circadian rhythms [130-133]. SIRT1 directs circadian oscillation in hepatocytes through rhythmic deacetylation of histone $\mathrm{H} 3$ at the promoter of clockcontrolled genes. Moreover, SIRT1 controls deacetylation of important circadian regulators such as BMAL1 and PER2 [130, 132]. Deficiency of liver-specific SIRT1 - using SIRT1KO (Sirt ${ }^{\text {LKO }}$ ) mice - as well as pharmacological modulation of SIRT1 expression lead to major changes in hepatic circadian gene expression and lipid metabolism [134, 135].

SIRT1 crucially acts as a sensor in metabolic and energy control of the cell $[136,137]$. SIRT1 activity is mediated by $\mathrm{NAD}^{+}$levels [138]. Because the liver is the major organ controlling homeostasis, it is clear that perturbations driven by high-fat or high-calorie diets, alcohol or drugs altering $\mathrm{NAD}^{+}$levels will all affect SIRT1 transcriptional activity [124, 139-141]. Several participants in liver homeostasis are regulated by SIRT1, most of them being transcription factors with a role in lipid metabolism, such as the peroxisome proliferator-activated receptor- $\alpha$ (PPAR $\alpha$ ), peroxisome proliferator-activated receptor- $\gamma$ coactivator-1 $\alpha$ (PGC-1 $\alpha$ ) [142], carbohydrate response element binding protein (ChREBP), sterol regulatory element binding protein-1c (SREBP-1) [143], and NF-KB [144, 145]. The control of SIRT1 occurs de facto via deacetylation of transcription factors involved in lipid metabolism [146]. SREBP-1c and ChREBP deacetylation is accompanied by an arrested transcription of downstream genes, leading to lipogenesis. PPAR $\alpha$ and PGC- $1 \alpha$ deacetylation promotes FA- $\beta$-oxidation. Owing to the role of SIRT1 in controlling liver lipid metabolism, many studies have been conducted in Sirt ${ }^{\mathrm{LKO}}$ mice [147]. In particular, it was found that Sirt ${ }^{\text {LKO }}$ mice, fed a normal diet, develop enhanced fat accumulation in their livers over their entire lifespans, indicating a clear participation of
SIRT1 in the onset of hepatic steatosis [147-150]. Indeed, more than with steatosis alone, the overall clinical picture is consistent with an underlying inflammatory condition and increased ROS production, both of which accompany the hyperglycemia and insulin resistance typically driven by steatosis in Sirt ${ }^{\text {LKO }}$ mice [151].

Interestingly, $\mathrm{PH}$ performed in Sirt ${ }^{\mathrm{LKO}}$ mice results in impaired liver regeneration, with a clear delay in the G1/S transition, deregulation of cyclins and related CDKs and delayed regeneration. Moreover, the regenerating liver from Sirt ${ }^{\mathrm{LO}}$ mice shows unusual accumulation of lipids, with increased levels of TAGs (triacylglycerol), NEFA (nonesterified fatty acid) and cholesterol, thus confirming the crucial role of SIRT1 in regulating fat in liver under regeneration. Notably, under the same conditions, liver regeneration is characterized by downregulation of PPAR $\alpha$-related genes, thus substantiating a role for SIRT1 in controlling PPAR $\alpha$ and, in turn, fatty acid $\beta$-oxidation [152]. These findings are in agreement with previous results in PPAR $\alpha$ KO mice, in which a delay occurs in liver regeneration relative to control counterparts. Overall it is clear that, by balancing fat composition, SIRT1 has an important role in liver regeneration [153].

The recent finding of an interaction between SIRT1 and ER stress in the liver has been receiving much attention [154]. Whether lack of SIRT1 after PH - leading to hepatic fat composition - drives ER-stress activation or, conversely, it is the lack of SIRT1 - resulting in unrestrained ER stress that matters so much, remains to be explained. On the one hand, many studies have demonstrated that SIRT1 overexpression alleviates ER stress; SIRT1 overexpression in obese mice is accompanied by a reduction in ER stress and steatosis [155-157]. On the other hand, recent studies have credited SIRT1 with an ability to control the activation of ER stress, by deacetyling the fundamental transcription factor XBP1, and by controlling elF $2 \alpha$, which triggers $E R$ stress [158]. Overall, the interplay between ER stress and SIRT1 is intricate and complex, but recent reports have been providing new insight into this relationship, mostly by focusing on the role of ER stress in controlling SIRT1. In vivo and in vitro experiments showed that, by activating the PI3K-AKT-GSK3b pathway, ER stress would induce expression of SIRT1 [159].

Interestingly, SIRT1 and ER stress share another important function in the liver. SIRT1 is a pivotal regulator of circadian rhythms in the liver, where it has an ability to deacetylate histone $\mathrm{H} 3$ in a rhythmic manner, which, in turn, controls the promoters of clock-controlled genes as well as BMAL1 and PER2 [130, 132]. Altered SIRT1 activity in the liver is reflected in an altered expression of circadian genes and lipid metabolism [134, 135]. Importantly, the circadian clock coordinates the activation of important genes regulating ER stress in the liver; an altered circadian rhythm perturbs ER stress and, consequently, lipid metabolism [160-162]. Increasing evidence is available regarding the relationship between lipid metabolism and circadian clock, with a focus on timing of food intake, liver stress and liver pathology (Fig.3). 


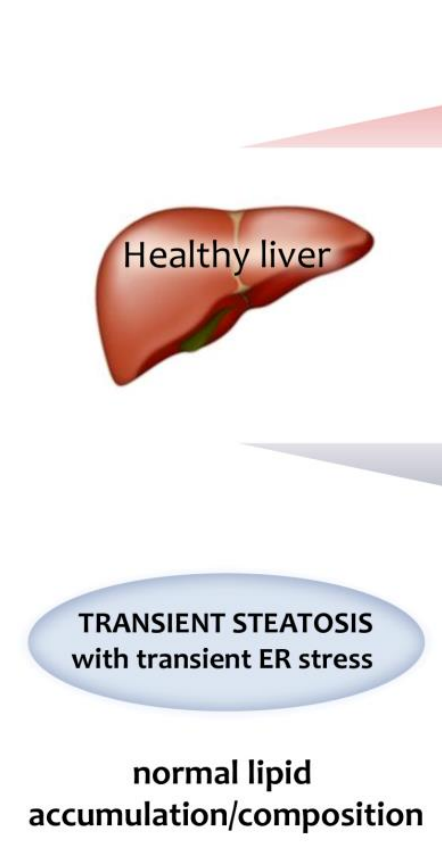

INJURIES

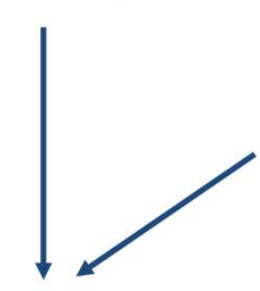

REGENERATION

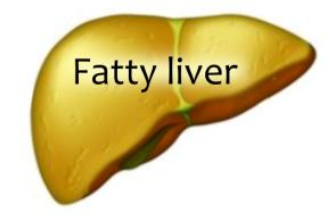

fat intake

high fat diet

alcohol \& drugs

SIRT1

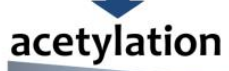

target activation

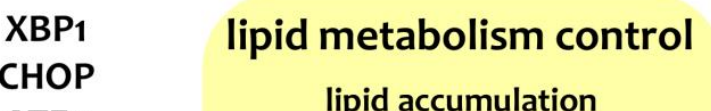

ATF4

$\downarrow$

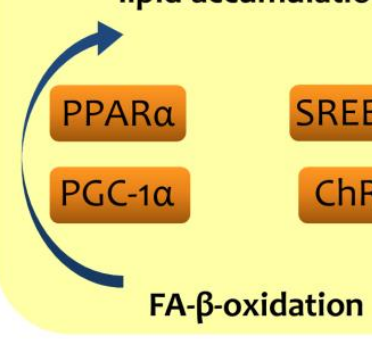

\section{Complete recovery}

SIRT3 is a mitochondrial protein, which plays an important role in the control of carbohydrate metabolism, ketogenesis, $\beta$-oxidation, and amino-acid metabolism [163]. Chronic high fat diet and obesity reduced SIRT3 activity, which in turn is associated with fatty liver. Indeed, analysis of SIRT3-KO mice shows no metabolic difference respect to the WT mice even if differences have been found in the mitochondrial acetylation proteins [164]. Hyperacetylation of mitochondrial protein found in SIRT3-KO mice accelerates the development of metabolic syndrome with steatohepatitis [165]. Recently, a study on pancreatic b-cells showed that SIRT3 is involved in the regulation of ER-stress down-regulating the gene expression of protein of ERstress [165]. SIRT6 and SIRT7 have been investigated to analyze their role in NAFLD. The analysis of Hepatocyte-

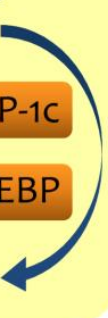

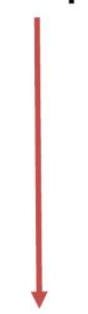

NO recovery
FIGURE 3: Lipid metabolism is crucial for liver regeneration. Fatty liver has an altered metabolism in lipids that affects its ability to regenerate after various injuries. Lipid accumulation during liver regeneration induces a transient steatosis with transient ER stress that is functional to proper proliferation of hepatocytes. On the contrary, the chronic steatosis and ER stress in fatty liver result in an altered lipid asset that could be addressed as the origin of the failure of regeneration. SIRT1, as a major player in lipid metabolism control, through its deacetylase activity on H3histone at gene promoters, controls the activation of various UPR genes such as XPB1, CHOP and ATF4.

Specific SIRT6-KO mice have revealed a predisposition to NAFLD when fed with a high-fat and high-fructose (HFHF) diet for 16 weeks. HFHF-diet induced in SIRT6-KO mice an increased in hepatic steatosis and inflammation with liver fibrosis and oxidative stress [166].

SIRT7 is a nuclear protein, highly expressed in the liver that regulates metabolic homeostasis [167]. It has been demonstrated that SIRT7 specific liver deficient mice develop steatosis with elevated expression of inflammatory markers indicating a turning towards NASH. Moreover, it has been revealed that in SIRT7 specific liver deficient mice the liver steatosis is not accompanied with obesity. Notably, it has been discovered that in liver SIRT7 regulates ERstress by repressing Myc activity [168]. 
Nevertheless, a clear picture of the complex relationship between Sirtuins and ER stress is still lacking (Table 1).

\section{CONCLUSIONS}

Liver regeneration represents a unique model for studying proliferation under conditions in which stable cells are induced to proliferate to rectify any parenchymal loss. Yet, the model is not simply meant to prove insight into a biological and legendary curiosity - the legend of Prometheus, chained to a rock, where an eagle ate his liver during the day, and the liver was regenerated during the night due to Prometheus' immortality. The knowledge, indeed, of the unique and complex mechanisms that determine liver regeneration might be of great help to a better understanding of liver pathology and to improved therapeutic and surgical interventions.

Broad panoply of events influences the ability of liver to regenerate, and recently fat liver accumulation has been receiving much attention, because of the high incidence of steatosis in humans. Macroscopic or severe steatosis has a

TABLE 1. Summary of effects of Non-alcoholic fatty liver disease (NAFLD) in various models on liver regeneration.

\begin{tabular}{|c|c|c|c|}
\hline Experimental model & $\begin{array}{l}\text { Factors that regulates its } \\
\text { expression/level }\end{array}$ & Effect & Reference \\
\hline High-Fat Diet & $\begin{array}{l}\text { IKB } \alpha, N F-K B, C y c l i n \text { D1 and } \\
\text { TNF- } \alpha\end{array}$ & $\begin{array}{l}\text { Development of increased body weight } \\
\text { Steatotic livers to increased injury through IKB } \alpha \text { over- } \\
\text { expression and subsequent NF-KB inhibition } \\
\text { Impaired liver regeneration }\end{array}$ & {$[21]$} \\
\hline $\mathrm{db} / \mathrm{db}$ mice & VEGF and EGFR & $\begin{array}{l}\text { Altered angiogenesis } \\
\text { Impaired liver re generation }\end{array}$ & {$[57,169]$} \\
\hline $\begin{array}{l}\text { ob/ob mice } \\
\mathrm{CCl} 4\end{array}$ & PEPCK, Cyclin D1 and TNF & $\begin{array}{l}\text { Altered rate-limiting enzyme for hepatic gluconeogen- } \\
\text { esis } \\
\text { Delay of expression of ciclyn D1 was insufficient to } \\
\text { drive the cells into S-phase } \\
\text { Defective TNF release by hepatic Kupffer cells and } \\
\text { circulating macrophages induces the impaired hepato- } \\
\text { cyte proliferation }\end{array}$ & {$[170]$} \\
\hline ob/ob mice & TNF, IL-6, STAT-3 and p21 & Impaired liver regeneration & $\begin{array}{l}{[19,171} \\
172]\end{array}$ \\
\hline $\begin{array}{l}\text { dietary fructose } \\
\text { compared to dietary } \\
\text { fat }\end{array}$ & $\begin{array}{l}\text { CPT-1, PPAR- } \alpha, \text { AMPK and } \\
\text { Cyp2E1 }\end{array}$ & $\begin{array}{l}\text { Steatosis } \\
\text { Impaired liver regeneration in fatty liver is related to } \\
\text { the cause, but not necessarily to the degree, of hepatic } \\
\text { steatosis. }\end{array}$ & [173] \\
\hline western diet (WD) & $\begin{array}{l}\text { TNFR-1, CD95/Fas, Noxa, } \\
\text { Bcl2, Bcl-xl, Mcl-1 and HGF }\end{array}$ & $\begin{array}{l}\text { Partial hepatectomy in steatotic liver doesn't affect } \\
\text { hepatocyte apoptosis, despite DR upregulation } \\
\text { WD-induced steatosis enhances liver cell proliferation, } \\
\text { which is accompanied by increased HGF and leptin } \\
\text { signaling as well as Erk1/2 phosphorylation }\end{array}$ & [174] \\
\hline Zucker (fa/fa) rats & PCNA and Cyclin E & $\begin{array}{l}\text { Steatosis per se does not impair liver regeneration. } \\
\text { The reduced liver regeneration observed in obese } \\
\text { Zucker rats may not be due to fatty infiltration itself } \\
\text { but to other factors such as leptin receptor dysfunc- } \\
\text { tion. }\end{array}$ & {$[56]$} \\
\hline
\end{tabular}


negative impact on regeneration of the liver in that it opposes proper regeneration in patients after surgical removal of neoplasia or in liver grafts. Moreover, because of the high incidence of NAFLD, steatosis represents a significant limitation to the availability of potential liver donors.

The knowledge of the molecular mechanisms governing liver regeneration and their impact on human liver pathology is becoming increasingly relevant in the clinical context. A better comprehension of the factors responsible for fat accumulation and their potential role in liver regeneration might permit the identification of novel druggable targets in hepatology [175].

\section{ACKNOWLEDGMENTS}

We thank Paolo Puccetti, Stefania Pieroni, Danilo Piobbico, Marilena Castelli and Damiano Scopetti for critical reading of the manuscript and helpful discussion. This study was supported by grants from Associazione Umbra Contro il Cancro

\section{REFERENCES}

1. Fausto N (2000). Liver regeneration. J Hepatol 32(1 Suppl): 19-31. PMID: 10728791

2. Michalopoulos GK, DeFrances MC (1997). Liver regeneration. Science 276(5309): 60-66. doi: 10.1126/science.276.5309.60

3. Taub R (2004). Liver regeneration: from myth to mechanism. Nat Rev Mol Cell Biol 5(10): 836-847. doi: 10.1038/nrm1489

4. Preziosi ME, Monga SP (2017). Update on the Mechanisms of Liver Regeneration. Semin Liver Dis 37(2): 141-151. doi: 10.1055/s-00371601351

5. Michalopoulos GK (2017). Hepatostat: Liver regeneration and normal liver tissue maintenance. Hepatology 65(4): 1384-1392. doi: 10.1002/hep. 28988

6. Kwon YJ, Lee KG, Choi D (2015). Clinical implications of advances in liver regeneration. Clin Mol Hepatol 21(1): 7-13. doi: 10.3350/cmh.2015.21.1.7

7. Huppert SS, Campbell KM (2016). Emerging advancements in liver regeneration and organogenesis as tools for liver replacement. Curr Opin Organ Transplant 21(6): 581-587. doi: 10.1097/MOT.0000000000000365

8. Nicolas CT, Hickey RD, Chen HS, Mao SA, Lopera Higuita M, Wang Y, Nyberg SL (2017). Concise Review: Liver Regenerative Medicine: From Hepatocyte Transplantation to Bioartificial Livers and Bioengineered Grafts. Stem Cells 35(1): 42-50. doi: 10.1002/stem.2500

9. Forbes SJ, Newsome PN (2016). Liver regeneration - mechanisms and models to clinical application. Nat Rev Gastroenterol Hepatol 13(8): 473-485. doi: 10.1038/nrgastro.2016.97

10. Speliotes EK, Massaro JM, Hoffmann U, Vasan RS, Meigs JB, Sahani DV, Hirschhorn JN, O'Donnell CJ, Fox CS (2010). Fatty liver is associated with dyslipidemia and dysglycemia independent of visceral fat: the Framingham Heart Study. Hepatology 51(6): 1979-1987. doi: 10.1002/hep.23593

11. Adams LA, Lymp JF, St Sauver J, Sanderson SO, Lindor KD, Feldstein A, Angulo $P$ (2005). The natural history of nonalcoholic fatty liver disease: a population-based cohort study. Gastroenterology 129(1): 113-121. doi: 10.1053/j.gastro.2005.04.014

12. Clark JM, Brancati FL, Diehl AM (2002). Nonalcoholic fatty liver disease. Gastroenterology 122(6): 1649-1657. PMID: 12016429
(AUCC) and Fondazione Cassa di Risparmio di Perugia and Comitato Maria Grazia Frasconi. G.S. is recipient of a PRIN 2015 Project 20152CB22L_004.

\section{CONFLICT OF INTEREST}

The authors declare no conflict of interest.

\section{COPYRIGHT}

(C) 2018 Della Fazia and Servillo. This is an open-access article released under the terms of the Creative Commons Attribution (CC BY) license, which allows the unrestricted use, distribution, and reproduction in any medium, provided the original author and source are acknowledged.

Please cite this article as: Maria Agnese Della Fazia and Giuseppe Servillo (2018). Foie gras and liver regeneration: a fat dilemma. Cell Stress 2(7): 162-175. doi: 10.15698/cst2018.07.144

13. Machado MV, Diehl AM (2016). Pathogenesis of Nonalcoholic Steatohepatitis. Gastroenterology 150(8): 1769-1777. doi: 10.1053/j.gastro.2016.02.066

14. McCullough AJ (2004). The clinical features, diagnosis and natural history of nonalcoholic fatty liver disease. Clin Liver Dis 8(3): 521-533. doi: 10.1016/j.cld.2004.04.004

15. Ong JP, Younossi ZM (2007). Epidemiology and natural history of NAFLD and NASH. Clin Liver Dis 11(1): 1-16. doi: 10.1016/j.cld.2007.02.009

16. Michelotti GA, Machado MV, Diehl AM (2013). NAFLD, NASH and liver cancer. Nat Rev Gastroenterol Hepatol 10(11): 656-665. doi: 10.1038/nrgastro.2013.183

17. Bellentani S, Saccoccio G, Masutti F, Croce LS, Brandi G, Sasso F, Cristanini G, Tiribelli C (2000). Prevalence of and risk factors for hepatic steatosis in Northern Italy. Ann Intern Med 132(2): 112-117. PMID: 10644271

18. Yasui K, Hashimoto E, Tokushige K, Koike K, Shima T, Kanbara Y, Saibara T, Uto H, Takami S, Kawanaka M, Komorizono Y, Okanoue T, Japan NSG (2012). Clinical and pathological progression of nonalcoholic steatohepatitis to hepatocellular carcinoma. Hepatol Res 42(8): 767-773. doi: 10.1111/j.1872-034X.2012.00986.x

19. Yang SQ, Lin HZ, Mandal AK, Huang J, Diehl AM (2001). Disrupted signaling and inhibited regeneration in obese mice with fatty livers: implications for nonalcoholic fatty liver disease pathophysiology. Hepatology 34(4 Pt 1): 694-706. doi: 10.1053/jhep.2001.28054

20. Hamano M, Ezaki H, Kiso S, Furuta K, Egawa M, Kizu T, Chatani N, Kamada $Y$, Yoshida $Y$, Takehara $T$ (2014). Lipid overloading during liver regeneration causes delayed hepatocyte DNA replication by increasing ER stress in mice with simple hepatic steatosis. J Gastroenterol 49(2): 305-316. doi: 10.1007/s00535-013-0780-7

21. DeAngelis RA, Markiewski MM, Taub R, Lambris JD (2005). A highfat diet impairs liver regeneration in C57BL/6 mice through overexpression of the NF-kappaB inhibitor, IkappaBalpha. Hepatology 42(5): 1148-1157. doi: 10.1002/hep.20879

22. Shteyer E, Liao Y, Muglia L, Hruz PW, Rudnick DA (2004). Disruption of hepatic adipogenesis is associated with impaired liver regeneration in mice. Hepatology 40(6): 1322-1332. doi: 10.1002/hep.20462 
23. Silver DL (2009). Hepatic Fatty Acid Metabolism and Dysfunction. In: Arias IM, editor The Liver: Biology and Pathobiology. John Wiley \& Sons, Ltd; pp 257-270. doi: 10.1002/9780470747919.ch18

24. Cohen DE (2009). Lipoprotein Metabolism and Cholesterol Balance. In: Arias IM, editor The Liver: Biology and Pathobiology. John Wiley \& Sons, Ltd; pp 271-285. doi: 10.1002/9780470747919.ch19

25. Oosterveer MH, Schoonjans K (2014). Hepatic glucose sensing and integrative pathways in the liver. Cell Mol Life Sci 71(8): 1453-1467. doi: 10.1007/s00018-013-1505-z

26. Wester TJ, Kraft G, Dardevet D, Polakof S, Ortigues-Marty I, Remond D, Savary-Auzeloux I (2015). Nutritional regulation of the anabolic fate of amino acids within the liver in mammals: concepts arising from in vivo studies. Nutr Res Rev 28(1): 22-41. doi: $10.1017 /$ S0954422415000013

27. Fausto N, Campbell JS, Riehle KJ (2012). Liver regeneration. J Hepatol 57(3): 692-694. doi: 10.1016/j.jhep.2012.04.016

28. Crawford BG (1918). Toxic Jaundice, with Atrophy of Liver, Followed by Regeneration and Recovery. Br Med J 1(2990): 450-451. PMID: 20769007

29. Diehl AM, Rai RM (1996). Liver regeneration 3: Regulation of signal transduction during liver regeneration. FASEB J 10(2): 215-227. PMID: 8641555

30. Taub R (1996). Liver regeneration 4: transcriptional control of liver regeneration. FASEB J 10(4): 413-427. PMID: 8647340

31. Fausto N, Laird AD, Webber EM (1995). Liver regeneration. 2. Role of growth factors and cytokines in hepatic regeneration. FASEB J 9(15): 1527-1536. PMID: 8529831

32. Servillo G, Della Fazia MA, Sassone-Corsi P (2002). Coupling CAMP signaling to transcription in the liver: pivotal role of CREB and CREM. Exp Cell Res 275(2): 143-154. doi: 10.1006/excr.2002.5491

33. Cressman DE, Greenbaum LE, DeAngelis RA, Ciliberto G, Furth EE, Poli V, Taub R (1996). Liver failure and defective hepatocyte regeneration in interleukin-6-deficient mice. Science 274(5291): 1379-1383. doi: $10.1126 /$ science. 274.5291 .1379

34. Yamada Y, Kirillova I, Peschon JJ, Fausto N (1997). Initiation of liver growth by tumor necrosis factor: deficient liver regeneration in mice lacking type I tumor necrosis factor receptor. Proc Natl Acad Sci U S A 94(4): 1441-1446. doi: 10.1073/pnas.94.4.1441

35. Servillo G, Della Fazia MA, Sassone-Corsi P (1998). Transcription factor CREM coordinates the timing of hepatocyte proliferation in the regenerating liver. Genes Dev 12(23): 3639-3643. doi: 10.1101/gad.12.23.3639

36. Fausto N, Campbell JS, Riehle KJ (2006). Liver regeneration. Hepatology 43(2 Suppl 1): S45-53. doi: 10.1002/hep.20969

37. Iwai M, Cui TX, Kitamura H, Saito M, Shimazu T (2001). Increased secretion of tumour necrosis factor and interleukin 6 from isolated, perfused liver of rats after partial hepatectomy. Cytokine 13(1): 60-64. doi: $10.1006 /$ cyto.2000.0797

38. Trautwein C, Rakemann T, Niehof M, Rose-John S, Manns MP (1996). Acute-phase response factor, increased binding, and target gene transcription during liver regeneration. Gastroenterology 110(6): 1854-1862. doi: 10.1053/gast.1996.v110.pm8964411

39. Su Al, Guidotti LG, Pezacki JP, Chisari FV, Schultz PG (2002). Gene expression during the priming phase of liver regeneration after partial hepatectomy in mice. Proc Natl Acad Sci U S A 99(17): 11181-11186. doi: 10.1073/pnas.122359899

40. Huh CG, Factor VM, Sanchez A, Uchida K, Conner EA, Thorgeirsson SS (2004). Hepatocyte growth factor/c-met signaling pathway is re- quired for efficient liver regeneration and repair. Proc Natl Acad Sci U S A 101(13): 4477-4482. doi: 10.1073/pnas.0306068101

41. Borowiak M, Garratt AN, Wustefeld T, Strehle M, Trautwein C, Birchmeier C (2004). Met provides essential signals for liver regeneration. Proc Natl Acad Sci U S A 101(29): 10608-10613. doi: 10.1073/pnas.0403412101

42. Argast GM, Campbell JS, Brooling JT, Fausto N (2004). Epidermal growth factor receptor transactivation mediates tumor necrosis factor-induced hepatocyte replication. J Biol Chem 279(33): 3453034536. doi: 10.1074/jbc.M405703200

43. Francavilla A, Ove P, Polimeno L, Sciascia C, Coetzee ML, Starzl TE (1986). Epidermal growth factor and proliferation in rat hepatocytes in primary culture isolated at different times after partial hepatectomy. Cancer Res 46(3): 1318-1323. PMID: 3002614

44. Talarmin H, Rescan C, Cariou S, Glaise D, Zanninelli G, Bilodeau M, Loyer P, Guguen-Guillouzo C, Baffet G (1999). The mitogen-activated protein kinase kinase/extracellular signal-regulated kinase cascade activation is a key signalling pathway involved in the regulation of $G(1)$ phase progression in proliferating hepatocytes. Mol Cell Biol 19(9): 6003-6011. doi: 10.1128/mcb.19.9.6003

45. Della Fazia MA, Piobbico D, Bartoli D, Castelli M, Brancorsini S, Viola Magni M, Servillo G (2002). lal-1: a differentially expressed novel gene during proliferation in liver regeneration and in hepatoma cells. Genes Cells 7(11): 1183-1190. doi: 10.1046/j.1365-2443.2002.00593.x

46. Della Fazia MA, Castelli M, Bartoli D, Pieroni S, Pettirossi V, Piobbico D, Viola-Magni M, Servillo G (2005). HOPS: a novel cAMPdependent shuttling protein involved in protein synthesis regulation. J Cell Sci 118(Pt 14): 3185-3194. doi: 10.1242/jcs.02452

47. Pieroni S, Della Fazia MA, Castelli M, Piobbico D, Bartoli D, Brunacci C, Bellet MM, Viola-Magni M, Servillo G (2008). HOPS is an essential constituent of centrosome assembly. Cell Cycle 7(10): 1462 1466. doi: $10.4161 /$ cc.7.10.5882

48. Castelli M, Pieroni S, Brunacci C, Piobbico D, Bartoli D, Bellet MM, Colombo E, Pelicci PG, Della Fazia MA, Servillo G (2013). Hepatocyte odd protein shuttling (HOPS) is a bridging protein in the nucleophosmin-p19 Arf network. Oncogene 32(28): 3350-3358. doi: 10.1038/onc. 2012.353

49. Bellet MM, Piobbico D, Bartoli D, Castelli M, Pieroni S, Brunacci C, Chiacchiaretta $M$, Del Sordo R, Fallarino F, Sidoni A, Puccetti P, Romani L, Servillo G, Della Fazia MA (2014). NEDD4 controls the expression of GUCD1, a protein upregulated in proliferating liver cells. Cell Cycle 13(12): 1902-1911. doi: 10.4161/cc.28760

50. Chen H, Lin Y, Sun W, Cai Y, Li H (2017). Liver Regeneration Is Impaired in Mice with Acute Exposure to a Very Low Carbohydrate Diet. Dig Dis Sci 62(5): 1256-1264. doi: 10.1007/s10620-017-4519-9

51. Holecek M (1999). Nutritional modulation of liver regeneration by carbohydrates, lipids, and amino acids: a review. Nutrition 15(10): 784-788. doi: 10.1016/s0899-9007(99)00158-6

52. Selzner M, Clavien PA (2000). Failure of regeneration of the steatotic rat liver: disruption at two different levels in the regeneration pathway. Hepatology 31(1): 35-42. doi: 10.1002/hep.510310108

53. Kachaylo E, Tschuor C, Calo N, Borgeaud N, Ungethum U, Limani $P$, Piguet AC, Dufour JF, Foti M, Graf R, Clavien PA, Humar B (2017). PTEN Down-Regulation Promotes beta-Oxidation to Fuel Hypertrophic Liver Growth After Hepatectomy in Mice. Hepatology 66(3): 908-921. doi: 10.1002/hep.29226

54. Zhang BH, Weltman M, Farrell GC (1999). Does steatohepatitis impair liver regeneration? A study in a dietary model of non-alcoholic steatohepatitis in rats. J Gastroenterol Hepatol 14(2): 133-137. PMID: 10029293 
55. Rao MS, Papreddy K, Abecassis M, Hashimoto T (2001). Regeneration of liver with marked fatty change following partial hepatectomy in rats. Dig Dis Sci 46(9): 1821-1826. PMID: 11575431

56. Picard C, Lambotte L, Starkel P, Sempoux C, Saliez A, Van den Berge V, Horsmans $Y$ (2002). Steatosis is not sufficient to cause an impaired regenerative response after partial hepatectomy in rats. J Hepatol 36(5): 645-652. doi: 10.1016/s0168-8278(02)00038-7

57. Yamauchi H, Uetsuka K, Okada T, Nakayama H, Doi K (2003). Impaired liver regeneration after partial hepatectomy in $\mathrm{db} / \mathrm{db}$ mice. Exp Toxicol Pathol 54(4): 281-286. doi: 10.1078/0940-2993-00265

58. Newberry EP, Kennedy SM, Xie Y, Luo J, Stanley SE, Semenkovich CF, Crooke RM, Graham MJ, Davidson NO (2008). Altered hepatic triglyceride content after partial hepatectomy without impaired liver regeneration in multiple murine genetic models. Hepatology 48(4): 1097-1105. doi: 10.1002/hep.22473

59. Glende EA, Jr., Morgan WS (1968). Alteration in liver lipid and lipid fatty acid composition after partial hepatectomy in the rat. Exp Mol Pathol 8(2): 190-200. PMID: 4296682

60. Gove CD, Hems DA (1978). Fatty acid synthesis in the regenerating liver of the rat. Biochem J 170(1): 1-8. doi: 10.1042/bj1700001

61. Delahunty TJ, Rubinstein D (1970). Accumulation and release of triglycerides by rat liver following partial hepatectomy. J Lipid Res 11(6): 536-543. PMID: 5504519

62. Camargo AC, Cornicelli J, Cardoso SS (1966). Alteration in lipid content of the liver in the rat after partial hepatectomy. Proc Soc Exp Biol Med 122(4): 1151-1154. doi: 10.3181/00379727-122-31349

63. Farrell GC (2004). Probing Prometheus: fat fueling the fire? Hepatology 40(6): 1252-1255. doi: 10.1002/hep.20522

64. Rudnick DA, Davidson NO (2012). Functional Relationships between Lipid Metabolism and Liver Regeneration. Int J Hepatol 2012: 549241. doi: 10.1155/2012/549241

65. Canbay A, Bechmann L, Gerken G (2007). Lipid metabolism in the liver. Z Gastroenterol 45(1): 35-41. doi: 10.1055/s-2006-927368

66. Borgese N, Francolini M, Snapp E (2006). Endoplasmic reticulum architecture: structures in flux. Curr Opin Cell Biol 18(4): 358-364. doi: 10.1016/j.ceb.2006.06.008

67. Han J, Kaufman RJ (2016). The role of ER stress in lipid metabolism and lipotoxicity. J Lipid Res 57(8): 1329-1338. doi: 10.1194/jlr.R067595

68. Drin G (2014). Topological regulation of lipid balance in cells. Annu Rev Biochem 83(51-77. doi: 10.1146/annurev-biochem-060713035307

69. Goldfarb S (1972). Submicrosomal localization of hepatic 3hydroxy-3-methylglutaryl coenzyme a (HMG-CoA) reductase. FEBS Lett 24(2): 153-155. doi: 10.1016/0014-5793(72)80755-5

70. Mandon EC, Ehses I, Rother J, van Echten G, Sandhoff K (1992). Subcellular localization and membrane topology of serine palmitoyltransferase, 3-dehydrosphinganine reductase, and sphinganine $\mathrm{N}$ acyltransferase in mouse liver. J Biol Chem 267(16): 11144-11148. PMID: 1317856

71. Hotamisligil GS (2010). Endoplasmic reticulum stress and the inflammatory basis of metabolic disease. Cell 140(6): 900-917. doi: 10.1016/j.cell.2010.02.034

72. Kaplowitz N, Than TA, Shinohara M, Ji C (2007). Endoplasmic reticulum stress and liver injury. Semin Liver Dis 27(4): 367-377. doi: 10.1055/s-2007-991513

73. Malhi H, Kaufman RJ (2011). Endoplasmic reticulum stress in liver disease. J Hepatol 54(4): 795-809. doi: 10.1016/j.jhep.2010.11.005
74. Bechmann LP, Hannivoort RA, Gerken G, Hotamisligil GS, Trauner $M$, Canbay A (2012). The interaction of hepatic lipid and glucose metabolism in liver diseases. J Hepatol 56(4): 952-964. doi: 10.1016/j.jhep.2011.08.025

75. Senft D, Ronai ZA (2015). UPR, autophagy, and mitochondria crosstalk underlies the ER stress response. Trends Biochem Sci 40(3): 141-148. doi: 10.1016/j.tibs.2015.01.002

76. Christianson JC, Olzmann JA, Shaler TA, Sowa ME, Bennett EJ, Richter CM, Tyler RE, Greenblatt EJ, Harper JW, Kopito RR (2011). Defining human ERAD networks through an integrative mapping strategy. Nat Cell Biol 14(1): 93-105. doi: 10.1038/ncb2383

77. Stevenson J, Huang EY, Olzmann JA (2016). Endoplasmic Reticulum-Associated Degradation and Lipid Homeostasis. Annu Rev Nutr 36: 511-542. doi: 10.1146/annurev-nutr-071715-051030

78. Hetz C, Chevet E, Oakes SA (2015). Proteostasis control by the unfolded protein response. Nat Cell Biol 17(7): 829-838. doi: $10.1038 /$ ncb3184

79. Lindholm D, Korhonen L, Eriksson O, Koks S (2017). Recent Insights into the Role of Unfolded Protein Response in ER Stress in Health and Disease. Front Cell Dev Biol 5(48. doi: 10.3389/fcell.2017.00048

80. Corazzari M, Gagliardi M, Fimia GM, Piacentini M (2017). Endoplasmic Reticulum Stress, Unfolded Protein Response, and Cancer Cell Fate. Front Oncol 7: 78. doi: 10.3389/fonc.2017.00078

81. Bahar E, Kim H, Yoon H (2016). ER Stress-Mediated Signaling: Action Potential and $\mathrm{Ca}(2+)$ as Key Players. Int J Mol Sci 17(9). doi: 10.3390/ijms17091558

82. Bertolotti A, Zhang Y, Hendershot LM, Harding HP, Ron D (2000). Dynamic interaction of BiP and ER stress transducers in the unfoldedprotein response. Nat Cell Biol 2(6): 326-332. doi: 10.1038/35014014

83. Harding HP, Zhang Y, Ron D (1999). Protein translation and folding are coupled by an endoplasmic-reticulum-resident kinase. Nature 397(6716): 271-274. doi: 10.1038/16729

84. Chen X, Shen J, Prywes R (2002). The luminal domain of ATF6 senses endoplasmic reticulum (ER) stress and causes translocation of ATF6 from the ER to the Golgi. J Biol Chem 277(15): 13045-13052. doi: 10.1074/jbc.M110636200

85. Shen J, Snapp EL, Lippincott-Schwartz J, Prywes R (2005). Stable binding of ATF6 to BiP in the endoplasmic reticulum stress response. Mol Cell Biol 25(3): 921-932. doi: 10.1128/MCB.25.3.921-932.2005

86. Donnelly N, Gorman AM, Gupta S, Samali A (2013). The elF2alpha kinases: their structures and functions. Cell Mol Life Sci 70(19): 34933511. doi: 10.1007/s00018-012-1252-6

87. Ma Y, Brewer JW, Diehl JA, Hendershot LM (2002). Two distinct stress signaling pathways converge upon the $\mathrm{CHOP}$ promoter during the mammalian unfolded protein response. J Mol Biol 318(5): 13511365. doi: 10.1016/s0022-2836(02)00234-6

88. Harding HP, Zhang Y, Scheuner D, Chen JJ, Kaufman RJ, Ron D (2009). Ppp1r15 gene knockout reveals an essential role for translation initiation factor 2 alpha (elF2alpha) dephosphorylation in mammalian development. Proc Natl Acad Sci U S A 106(6): 1832-1837. doi: 10.1073/pnas.0809632106

89. Romano PR, Garcia-Barrio MT, Zhang X, Wang Q, Taylor DR, Zhang F, Herring C, Mathews MB, Qin J, Hinnebusch AG (1998). Autophosphorylation in the activation loop is required for full kinase activity in vivo of human and yeast eukaryotic initiation factor 2alpha kinases PKR and GCN2. Mol Cell Biol 18(4): 2282-2297. doi: $10.1128 / \mathrm{mcb} .18 .4 .2282$

90. Tirasophon W, Lee K, Callaghan B, Welihinda A, Kaufman RJ (2000). The endoribonuclease activity of mammalian IRE1 autoregu- 
lates its mRNA and is required for the unfolded protein response. Genes Dev 14(21): 2725-2736. doi: 10.1101/gad.839400

91. Yoshida H, Matsui T, Yamamoto A, Okada T, Mori K (2001). XBP1 mRNA is induced by ATF6 and spliced by IRE1 in response to ER stress to produce a highly active transcription factor. Cell 107(7): 881-891. doi: 10.1016/s0092-8674(01)00611-0

92. Wu R, Zhang QH, Lu YJ, Ren K, Yi GH (2015). Involvement of the IRE1alpha-XBP1 pathway and XBP1s-dependent transcriptional reprogramming in metabolic diseases. DNA Cell Biol 34(1): 6-18. doi: 10.1089/dna.2014.2552

93. Acosta-Alvear D, Zhou $\mathrm{Y}$, Blais A, Tsikitis $\mathrm{M}$, Lents $\mathrm{NH}$, Arias $\mathrm{C}$, Lennon CJ, Kluger Y, Dynlacht BD (2007). XBP1 controls diverse cell type- and condition-specific transcriptional regulatory networks. Mol Cell 27(1): 53-66. doi: 10.1016/j.molcel.2007.06.011

94. Ye J, Rawson RB, Komuro R, Chen X, Dave UP, Prywes R, Brown MS, Goldstein JL (2000). ER stress induces cleavage of membranebound ATF6 by the same proteases that process SREBPs. Mol Cell 6(6): 1355-1364. doi: 10.1016/s1097-2765(00)00133-7

95. Hetz C, Papa FR (2017). The Unfolded Protein Response and Cell Fate Control. Mol Cell. doi: 10.1016/j.molcel.2017.06.017

96. Song S, Tan J, Miao Y, Li M, Zhang Q (2017). Crosstalk of autophagy and apoptosis: Involvement of the dual role of autophagy under ER stress. J Cell Physiol 232(11): 2977-2984. doi: 10.1002/jcp.25785

97. Wei Y, Wang D, Topczewski F, Pagliassotti MJ (2006). Saturated fatty acids induce endoplasmic reticulum stress and apoptosis independently of ceramide in liver cells. Am J Physiol Endocrinol Metab 291(2): E275-281. doi: 10.1152/ajpendo.00644.2005

98. Wang D, Wei Y, Pagliassotti MJ (2006). Saturated fatty acids promote endoplasmic reticulum stress and liver injury in rats with hepatic steatosis. Endocrinology 147(2): 943-951. doi: 10.1210/en.2005-0570

99. Puri P, Mirshahi F, Cheung O, Natarajan R, Maher JW, Kellum JM, Sanyal AJ (2008). Activation and dysregulation of the unfolded protein response in nonalcoholic fatty liver disease. Gastroenterology 134(2): 568-576. doi: 10.1053/j.gastro.2007.10.039

100. Mota M, Banini BA, Cazanave SC, Sanyal AJ (2016). Molecular mechanisms of lipotoxicity and glucotoxicity in nonalcoholic fatty liver disease. Metabolism 65(8): 1049-1061. doi: 10.1016/j.metabol.2016.02.014

101. Liu Y, Shao M, Wu Y, Yan C, Jiang S, Liu J, Dai J, Yang L, Li J, Jia W, Rui $L$, Liu $Y$ (2015). Role for the endoplasmic reticulum stress sensor IRE1alpha in liver regenerative responses. J Hepatol 62(3): 590-598. doi: 10.1016/j.jhep.2014.10.022

102. Inaba $Y$, Furutani $T$, Kimura $K$, Watanabe $H$, Haga $S$, Kido $Y$, Matsumoto M, Yamamoto Y, Harada K, Kaneko S, Oyadomari S, Ozaki $M$, Kasuga $M$, Inoue $H$ (2015). Growth arrest and DNA damageinducible 34 regulates liver regeneration in hepatic steatosis in mice. Hepatology 61(4): 1343-1356. doi: 10.1002/hep.27619

103. Shao M, Shan B, Liu Y, Deng Y, Yan C, Wu Y, Mao T, Qiu Y, Zhou Y, Jiang S, Jia W, Li J, Li J, Rui L, Yang L, Liu Y (2014). Hepatic IRE1alpha regulates fasting-induced metabolic adaptive programs through the XBP1s-PPARalpha axis signalling. Nat Commun 5: 3528 . doi: $10.1038 /$ ncomms 4528

104. Bartoli D, Piobbico D, Bellet MM, Bennati AM, Roberti R, Della Fazia MA, Servillo G (2016). Impaired cell proliferation in regenerating liver of 3 beta-hydroxysterol Delta14-reductase (TM7SF2) knock-out mice. Cell Cycle 15(16): 2164-2173. doi: 10.1080/15384101.2016.1195939

105. Lee S, Kim S, Hwang S, Cherrington NJ, Ryu DY (2017). Dysregulated expression of proteins associated with ER stress, autophagy and apoptosis in tissues from nonalcoholic fatty liver disease. Oncotarget 8(38): 63370-63381. doi: 10.18632/oncotarget.18812

106. Ma C, Zhang Q, Greten TF (2017). Nonalcoholic fatty liver disease promotes hepatocellular carcinoma through direct and indirect effects on hepatocytes. FEBS J 285(4):752-762. doi: 10.1111/febs.14209

107. Pagliassotti MJ, Kim PY, Estrada AL, Stewart CM, Gentile CL (2016). Endoplasmic reticulum stress in obesity and obesity-related disorders: An expanded view. Metabolism 65(9): 1238-1246. doi: 10.1016/j.metabol.2016.05.002

108. Hyslop PA, York DA, Corina DL (1982). Changes in the composition and fluidity of membranes in obese (ob/ob) mice: a study of hepatic microsomal NADPH-cytochrome P450 oxidoreductase activity. Int J Obes 6(3): 279-289. PMID: 6811450

109. Fu S, Yang L, Li P, Hofmann O, Dicker L, Hide W, Lin X, Watkins SM, Ivanov AR, Hotamisligil GS (2011). Aberrant lipid metabolism disrupts calcium homeostasis causing liver endoplasmic reticulum stress in obesity. Nature 473(7348): 528-531. doi: $10.1038 /$ nature09968

110. Arruda AP, Hotamisligil GS (2015). Calcium Homeostasis and Organelle Function in the Pathogenesis of Obesity and Diabetes. Cell Metab 22(3): 381-397. doi: 10.1016/j.cmet.2015.06.010

111. Kammoun HL, Chabanon $\mathrm{H}$, Hainault I, Luquet $\mathrm{S}$, Magnan $\mathrm{C}$, Koike T, Ferre P, Foufelle F (2009). GRP78 expression inhibits insulin and ER stress-induced SREBP-1c activation and reduces hepatic steatosis in mice. J Clin Invest 119(5): 1201-1215. doi: 10.1172/JCl37007

112. Lee JS, Mendez R, Heng HH, Yang ZQ, Zhang K (2012). Pharmacological ER stress promotes hepatic lipogenesis and lipid droplet formation. Am J Transl Res 4(1): 102-113. PMID: 22347525

113. Wang Y, Viscarra J, Kim SJ, Sul HS (2015). Transcriptional regulation of hepatic lipogenesis. Nat Rev Mol Cell Biol 16(11): 678-689. doi: $10.1038 / \mathrm{nrm} 4074$

114. Jo H, Choe SS, Shin KC, Jang H, Lee JH, Seong JK, Back SH, Kim JB (2013). Endoplasmic reticulum stress induces hepatic steatosis via increased expression of the hepatic very low-density lipoprotein receptor. Hepatology 57(4): 1366-1377. doi: 10.1002/hep.26126

115. Alvarez-Sola G, Uriarte I, Latasa MU, Fernandez-Barrena MG, Urtasun R, Elizalde M, Barcena-Varela M, Jimenez M, Chang HC, Barbero R, Catalan V, Rodriguez A, Fruhbeck G, Gallego-Escuredo JM, Gavalda-Navarro A, Villarroya F, Rodriguez-Ortigosa CM, Corrales FJ, Prieto J, Berraondo P, Berasain C, Avila MA (2017). Fibroblast growth factor 15/19 (FGF15/19) protects from diet-induced hepatic steatosis: development of an FGF19-based chimeric molecule to promote fatty liver regeneration. Gut 66(10): 1818-1828. doi: 10.1136/gutjnl-2016312975

116. Yu Y, Tamai M, Tagawa YI (2017). Nitric oxide is critical for avoiding hepatic lipid overloading via IL-6 induction during liver regeneration after partial hepatectomy in mice. Exp Anim 66(4): 293-302. doi: 10.1538/expanim.17-0017

117. Zhang L, Ren F, Zhang X, Wang X, Shi H, Zhou L, Zheng S, Chen Y, Chen D, Li L, Zhao C, Duan Z (2016). Peroxisome proliferator-activated receptor alpha acts as a mediator of endoplasmic reticulum stressinduced hepatocyte apoptosis in acute liver failure. Dis Model Mech 9(7): 799-809. doi: 10.1242/dmm.023242

118. Enkhbold C, Morine $\mathrm{Y}$, Utsunomiya T, Imura S, Ikemoto T, Arakawa Y, Saito Y, Yamada S, Ishikawa D, Shimada M (2015). Dysfunction of liver regeneration in aged liver after partial hepatectomy. J Gastroenterol Hepatol 30(7): 1217-1224. doi: 10.1111/jgh.12930

119. Ben Mosbah I, Alfany-Fernandez I, Martel C, Zaouali MA, Bintanel-Morcillo M, Rimola A, Rodes J, Brenner C, Rosello-Catafau J, Peralta $C$ (2010). Endoplasmic reticulum stress inhibition protects 
steatotic and non-steatotic livers in partial hepatectomy under ischemia-reperfusion. Cell Death Dis 1: e52. doi: 10.1038/cddis.2010.29

120. Wada S, Hatano E, Yoh T, Nakamura N, Okuda Y, Okuno M, Kasai $Y$, Iwaisako K, Seo S, Taura K, Uemoto S (2018). CAAT/enhancer binding protein-homologous protein deficiency attenuates liver ischemia/reperfusion injury in mice. Liver Transpl 24(5): 645-654. doi: 10.1002/It.25053

121. Kugel S, Mostoslavsky R (2014). Chromatin and beyond: the multitasking roles for SIRT6. Trends Biochem Sci 39(2): 72-81. doi: 10.1016/j.tibs.2013.12.002

122. Finkel T, Deng CX, Mostoslavsky R (2009). Recent progress in the biology and physiology of sirtuins. Nature 460(7255): 587-591. doi: $10.1038 /$ nature08197

123. Michishita E, Park JY, Burneskis JM, Barrett JC, Horikawa I (2005). Evolutionarily conserved and nonconserved cellular localizations and functions of human SIRT proteins. Mol Biol Cell 16(10): 4623-4635. doi: 10.1091/mbc.E05-01-0033

124. Nassir F, Ibdah JA (2016). Sirtuins and nonalcoholic fatty liver disease. World J Gastroenterol 22(46): 10084-10092. doi: 10.3748/wjg.v22.i46.10084

125. Lombard DB, Alt FW, Cheng HL, Bunkenborg J, Streeper RS, Mostoslavsky R, Kim J, Yancopoulos G, Valenzuela D, Murphy A, Yang Y, Chen $Y$, Hirschey MD, Bronson RT, Haigis M, Guarente LP, Farese RV, Jr., Weissman S, Verdin E, Schwer B (2007). Mammalian Sir2 homolog SIRT3 regulates global mitochondrial lysine acetylation. Mol Cell Biol 27(24): 8807-8814. doi: 10.1128/МСB.01636-07

126. Kendrick AA, Choudhury M, Rahman SM, McCurdy CE, Friederich M, Van Hove JL, Watson PA, Birdsey N, Bao J, Gius D, Sack MN, Jing E, Kahn CR, Friedman JE, Jonscher KR (2011). Fatty liver is associated with reduced SIRT3 activity and mitochondrial protein hyperacetylation. Biochem J 433(3): 505-514. doi: 10.1042/BJ20100791

127. Furukawa $S$, Fujita $T$, Shimabukuro $M$, Iwaki $M$, Yamada $Y$, Nakajima Y, Nakayama O, Makishima M, Matsuda M, Shimomura I (2004). Increased oxidative stress in obesity and its impact on metabolic syndrome. J Clin Invest 114(12): 1752-1761. doi: $10.1172 / \mathrm{JCl} 21625$

128. Urakawa H, Katsuki A, Sumida Y, Gabazza EC, Murashima S, Morioka K, Maruyama N, Kitagawa N, Tanaka T, Hori Y, Nakatani K, Yano $Y$, Adachi $Y$ (2003). Oxidative stress is associated with adiposity and insulin resistance in men. J Clin Endocrinol Metab 88(10): 4673-4676. doi: 10.1210/jc.2003-030202

129. Guarente L (2011). Sirtuins, aging, and metabolism. Cold Spring Harb Symp Quant Biol 76(81-90. doi: 10.1101/sqb.2011.76.010629

130. Asher G, Gatfield D, Stratmann M, Reinke H, Dibner C, Kreppel F, Mostoslavsky R, Alt FW, Schibler U (2008). SIRT1 regulates circadian clock gene expression through PER2 deacetylation. Cell 134(2): $317-$ 328. doi: 10.1016/j.cell.2008.06.050

131. Chang HC, Guarente L (2013). SIRT1 mediates central circadian control in the SCN by a mechanism that decays with aging. Cell 153(7): 1448-1460. doi: 10.1016/j.cell.2013.05.027

132. Nakahata Y, Kaluzova M, Grimaldi B, Sahar S, Hirayama J, Chen D, Guarente LP, Sassone-Corsi P (2008). The NAD+-dependent deacetylase SIRT1 modulates CLOCK-mediated chromatin remodeling and circadian control. Cell 134(2): 329-340. doi: 10.1016/j.cell.2008.07.002

133. Nakahata $Y$, Sahar S, Astarita G, Kaluzova M, Sassone-Corsi P (2009). Circadian control of the NAD+ salvage pathway by CLOCKSIRT1. Science 324(5927): 654-657. doi: 10.1126/science.1170803

134. Bellet MM, Nakahata Y, Boudjelal M, Watts E, Mossakowska DE, Edwards KA, Cervantes M, Astarita G, Loh C, Ellis JL, Vlasuk GP, Sassone-Corsi $P$ (2013). Pharmacological modulation of circadian rhythms by synthetic activators of the deacetylase SIRT1. Proc Natl Acad Sci U S A 110(9): 3333-3338. doi: 10.1073/pnas. 1214266110

135. Masri S, Rigor P, Cervantes M, Ceglia N, Sebastian C, Xiao C, Roqueta-Rivera M, Deng C, Osborne TF, Mostoslavsky R, Baldi P, Sassone-Corsi $P$ (2014). Partitioning circadian transcription by SIRT6 leads to segregated control of cellular metabolism. Cell 158(3): 659-672. doi: 10.1016/j.cell.2014.06.050

136. Sahar S, Sassone-Corsi P (2009). Metabolism and cancer: the circadian clock connection. Nat Rev Cancer 9(12): 886-896. doi: $10.1038 / \mathrm{nrc} 2747$

137. Ding RB, Bao J, Deng CX (2017). Emerging roles of SIRT1 in fatty liver diseases. Int J Biol Sci 13(7): 852-867. doi: 10.7150/ijbs.19370

138. Rajamohan SB, Pillai VB, Gupta M, Sundaresan NR, Birukov KG, Samant S, Hottiger MO, Gupta MP (2009). SIRT1 promotes cell survival under stress by deacetylation-dependent deactivation of poly(ADPribose) polymerase 1. Mol Cell Biol 29(15): 4116-4129. doi: 10.1128/MCB.00121-09

139. Deng XQ, Chen LL, Li NX (2007). The expression of SIRT1 in nonalcoholic fatty liver disease induced by high-fat diet in rats. Liver Int 27(5): 708-715. doi: 10.1111/j.1478-3231.2007.01497.x

140. Purushotham A, Schug TT, Xu Q, Surapureddi S, Guo X, Li X (2009). Hepatocyte-specific deletion of SIRT1 alters fatty acid metabolism and results in hepatic steatosis and inflammation. Cell Metab 9(4): 327-338. doi: 10.1016/j.cmet.2009.02.006

141. Ramirez T, Li YM, Yin S, Xu MJ, Feng D, Zhou Z, Zang M, Mukhopadhyay $P$, Varga ZV, Pacher $P$, Gao B, Wang H (2017). Aging aggravates alcoholic liver injury and fibrosis in mice by downregulating sirtuin 1 expression. J Hepatol 66(3): 601-609. doi: 10.1016/j.jhep.2016.11.004

142. Sugden MC, Caton PW, Holness MJ (2010). PPAR control: it's SIRTainly as easy as PGC. J Endocrinol 204(2): 93-104. doi: 10.1677/JOE-09-0359

143. Ponugoti B, Kim DH, Xiao Z, Smith Z, Miao J, Zang M, Wu SY, Chiang CM, Veenstra TD, Kemper JK (2010). SIRT1 deacetylates and inhibits SREBP-1C activity in regulation of hepatic lipid metabolism. J Biol Chem 285(44): 33959-33970. doi: 10.1074/jbc.M110.122978

144. Li X, Kazgan N (2011). Mammalian sirtuins and energy metabolism. Int J Biol Sci 7(5): 575-587. doi: 10.7150/ijbs.7.575

145. Simmons GE, Jr., Pruitt WM, Pruitt K (2015). Diverse roles of SIRT1 in cancer biology and lipid metabolism. Int J Mol Sci 16(1): 950965. doi: 10.3390/ijms16010950

146. Kemper JK, Choi SE, Kim DH (2013). Sirtuin 1 deacetylase: a key regulator of hepatic lipid metabolism. Vitam Horm 91(385-404. doi: 10.1016/B978-0-12-407766-9.00016-X

147. Chen D, Bruno J, Easlon E, Lin SJ, Cheng HL, Alt FW, Guarente L (2008). Tissue-specific regulation of SIRT1 by calorie restriction. Genes Dev 22(13): 1753-1757. doi: 10.1101/gad.1650608

148. Wang RH, Li C, Deng CX (2010). Liver steatosis and increased ChREBP expression in mice carrying a liver specific SIRT1 null mutation under a normal feeding condition. Int J Biol Sci 6(7): 682-690. doi: $10.7150 /$ ijbs.6.682

149. Choi SE, Kwon S, Seok S, Xiao Z, Lee KW, Kang Y, Li X, Shinoda K, Kajimura S, Kemper B, Kemper JK (2017). Obesity-Linked Phosphorylation of SIRT1 by Casein Kinase 2 Inhibits Its Nuclear Localization and Promotes Fatty Liver. Mol Cell Biol 37(15). doi: 10.1128/MCB.0000617

150. Pfluger PT, Herranz D, Velasco-Miguel S, Serrano M, Tschop MH (2008). Sirt1 protects against high-fat diet-induced metabolic damage. Proc Natl Acad Sci U S A 105(28): 9793-9798. doi: 10.1073/pnas.0802917105 
151. Wang RH, Kim HS, Xiao C, Xu X, Gavrilova O, Deng CX (2011). Hepatic Sirt1 deficiency in mice impairs mTorc2/Akt signaling and results in hyperglycemia, oxidative damage, and insulin resistance. J Clin Invest 121(11): 4477-4490. doi: 10.1172/JCI46243

152. Bellet MM, Masri S, Astarita G, Sassone-Corsi P, Della Fazia MA, Servillo G (2016). Histone Deacetylase SIRT1 Controls Proliferation, Circadian Rhythm, and Lipid Metabolism during Liver Regeneration in Mice. J Biol Chem 291(44): 23318-23329. doi: 10.1074/jbc.M116.737114

153. Anderson SP, Yoon L, Richard EB, Dunn CS, Cattley RC, Corton JC (2002). Delayed liver regeneration in peroxisome proliferatoractivated receptor-alpha-null mice. Hepatology 36(3): 544-554. doi: 10.1053/jhep.2002.35276

154. Zheng $X, X u F$, Liang $H$, Cao $H$, Cai M, Xu W, Weng J (2017). SIRT1/HSF1/HSP pathway is essential for exenatide-alleviated, lipidinduced hepatic endoplasmic reticulum stress. Hepatology 66(3): 809824. doi: $10.1002 /$ hep. 29238

155. Li Y, Xu S, Giles A, Nakamura K, Lee JW, Hou X, Donmez G, Li J, Luo Z, Walsh K, Guarente L, Zang M (2011). Hepatic overexpression of SIRT1 in mice attenuates endoplasmic reticulum stress and insulin resistance in the liver. FASEB J 25(5): 1664-1679. doi: 10.1096/fj.10173492

156. Ding S, Jiang J, Zhang G, Bu Y, Zhang G, Zhao X (2017). Resveratrol and caloric restriction prevent hepatic steatosis by regulating SIRT1autophagy pathway and alleviating endoplasmic reticulum stress in high-fat diet-fed rats. PLoS One 12(8): e0183541. doi: 10.1371/journal.pone.0183541

157. Jung TW, Lee KT, Lee MW, Ka KH (2012). SIRT1 attenuates palmitate-induced endoplasmic reticulum stress and insulin resistance in HepG2 cells via induction of oxygen-regulated protein 150. Biochem Biophys Res Commun 422(2): 229-232. doi: 10.1016/j.bbrc.2012.04.129

158. Wang FM, Chen YJ, Ouyang HJ (2011). Regulation of unfolded protein response modulator XBP1s by acetylation and deacetylation. Biochem J 433(1): 245-252. doi: 10.1042/BJ20101293

159. Koga T, Suico MA, Shimasaki S, Watanabe E, Kai Y, Koyama K, Omachi K, Morino-Koga S, Sato T, Shuto T, Mori K, Hino S, Nakao M, Kai H (2015). Endoplasmic Reticulum (ER) Stress Induces Sirtuin 1 (SIRT1) Expression via the PI3K-Akt-GSK3beta Signaling Pathway and Promotes Hepatocellular Injury. J Biol Chem 290(51): 30366-30374. doi: 10.1074/jbc.M115.664169

160. Cretenet G, Le Clech M, Gachon F (2010). Circadian clockcoordinated $12 \mathrm{Hr}$ period rhythmic activation of the IRE1alpha pathway controls lipid metabolism in mouse liver. Cell Metab 11(1): 47-57. doi: 10.1016/j.cmet.2009.11.002

161. Maillo C, Martin J, Sebastian D, Hernandez-Alvarez M, GarciaRocha M, Reina O, Zorzano A, Fernandez M, Mendez R (2017). Circadian- and UPR-dependent control of CPEB4 mediates a translational response to counteract hepatic steatosis under ER stress. Nat Cell Biol 19(2): 94-105. doi: 10.1038/ncb3461

162. Soeda J, Cordero P, Li J, Mouralidarane A, Asilmaz E, Ray S, Nguyen V, Carter R, Novelli M, Vinciguerra M, Poston L, Taylor PD, Oben JA (2017). Hepatic rhythmicity of endoplasmic reticulum stress is disrupted in perinatal and adult mice models of high-fat diet-induced obesity. Int J Food Sci Nutr 68(4): 455-466. doi: 10.1080/09637486.2016.1261086

163. Nogueiras R, Habegger KM, Chaudhary N, Finan B, Banks AS, Dietrich MO, Horvath TL, Sinclair DA, Pfluger PT, Tschop MH (2012). Sirtuin 1 and sirtuin 3: physiological modulators of metabolism. Physiol Rev 92(3): 1479-1514. doi: 10.1152/physrev.00022.2011
164. Hebert AS, Dittenhafer-Reed KE, Yu W, Bailey DJ, Selen ES, Boersma MD, Carson JJ, Tonelli M, Balloon AJ, Higbee AJ, Westphall MS, Pagliarini DJ, Prolla TA, Assadi-Porter F, Roy S, Denu JM, Coon JJ (2013). Calorie restriction and SIRT3 trigger global reprogramming of the mitochondrial protein acetylome. Mol Cell 49(1): 186-199. doi: 10.1016/j.molcel.2012.10.024

165. Hirschey MD, Shimazu T, Jing E, Grueter CA, Collins AM, Aouizerat B, Stancakova A, Goetzman E, Lam MM, Schwer B, Stevens RD, Muehlbauer MJ, Kakar S, Bass NM, Kuusisto J, Laakso M, Alt FW, Newgard CB, Farese RV, Jr., Kahn CR, Verdin E (2011). SIRT3 deficiency and mitochondrial protein hyperacetylation accelerate the development of the metabolic syndrome. Mol Cell 44(2): 177-190. doi: 10.1016/j.molcel.2011.07.019

166. Ka SO, Bang IH, Bae EJ, Park BH (2017). Hepatocyte-specific sirtuin 6 deletion predisposes to nonalcoholic steatohepatitis by upregulation of Bach1, an Nrf2 repressor. FASEB J 31(9): 3999-4010. doi: 10.1096/fj.201700098RR

167. Ford E, Voit R, Liszt G, Magin C, Grummt I, Guarente L (2006). Mammalian Sir2 homolog SIRT7 is an activator of RNA polymerase I transcription. Genes Dev 20(9): 1075-1080. doi: 10.1101/gad.1399706

168. Shin J, He M, Liu Y, Paredes S, Villanova L, Brown K, Qiu X, Nabavi $\mathrm{N}$, Mohrin M, Wojnoonski K, Li P, Cheng HL, Murphy AJ, Valenzuela DM, Luo H, Kapahi P, Krauss R, Mostoslavsky R, Yancopoulos GD, Alt FW, Chua KF, Chen D (2013). SIRT7 represses Myc activity to suppress ER stress and prevent fatty liver disease. Cell Rep 5(3): 654-665. doi: 10.1016/j.celrep.2013.10.007

169. Uetsuka K, Shirai M, Yamauchi H, Nakayama H, Doi K (2005). Impaired proliferation of non-parenchymal cells participates in an impairment of liver regeneration in db/db mice. Exp Mol Pathol 79(1): 51-58. doi: 10.1016/j.yexmp.2005.02.002

170. Leclercq IA, Field J, Farrell GC (2003). Leptin-specific mechanisms for impaired liver regeneration in ob/ob mice after toxic injury. Gastroenterology 124(5): 1451-1464. doi: 10.1016/s0016-5085(03)002701

171. Leclercq IA, Vansteenberghe M, Lebrun VB, VanHul NK, AbarcaQuinones J, Sempoux CL, Picard C, Starkel P, Horsmans YL (2006). Defective hepatic regeneration after partial hepatectomy in leptindeficient mice is not rescued by exogenous leptin. Lab Invest $86(11)$ : 1161-1171. doi: 10.1038/labinvest.3700474

172. Torbenson M, Yang SQ, Liu HZ, Huang J, Gage W, Diehl AM (2002). STAT-3 overexpression and p21 up-regulation accompany impaired regeneration of fatty livers. Am J Pathol 161(1): 155-161. doi: 10.1016/S0002-9440(10)64167-3

173. Tanoue S, Uto H, Kumamoto R, Arima S, Hashimoto S, Nasu Y, Takami Y, Moriuchi A, Sakiyama T, Oketani M, Ido A, Tsubouchi $\mathrm{H}$ (2011). Liver regeneration after partial hepatectomy in rat is more impaired in a steatotic liver induced by dietary fructose compared to dietary fat. Biochem Biophys Res Commun 407(1): 163-168. doi: 10.1016/j.bbrc.2011.02.131

174. Sydor S, Gu Y, Schlattjan M, Bechmann LP, Rauen U, Best J, Paul A, Baba HA, Sowa JP, Gerken G, Canbay A (2013). Steatosis does not impair liver regeneration after partial hepatectomy. Lab Invest 93(1): 20-30. doi: 10.1038/labinvest.2012.142

175. Hetz C, Chevet E, Harding HP (2013). Targeting the unfolded protein response in disease. Nat Rev Drug Discov 12(9): 703-719. doi: $10.1038 / \mathrm{nrd} 3976$ 